\title{
LOW DIETARY PROTEIN INTAKES AND ASSOCIATED DIETARY PATTERNS AND FUNCTIONAL LIMITATIONS IN AN AGING POPULATION: A NHANES ANALYSIS
}

\author{
J.L. KROK-SCHOEN ${ }^{1}$, A. ARCHDEACON PRICE ${ }^{1}$, M. LUO ${ }^{2}$, O.J. KELLY², C.A. TAYLOR ${ }^{1}$ \\ 1. Ohio State University, Columbus, Ohio, USA; 2. Abbott Nutrition, Columbus, Ohio, USA. Corresponding author: Christopher Alan Taylor, Ohio State University, Columbus, Ohio, \\ USA, taylor.1043@osu.edu
}

\begin{abstract}
Objective: To investigate protein intakes across demographic characteristics in relation to dietary patterns and functional outcomes in older adults. Design: Observational and cross-sectional study. Setting: Non-institutionalized participants from the 2005-2014 National Health and Nutrition Examination Survey. Participants: Data from 11,680 adults were categorized into 51-60 years $(\mathrm{n}=4,016), 61-70$ years $(\mathrm{n}=3,854)$, and 71 years and older $(\mathrm{n}=3,810)$ for analysis. Measurements: Adults were stratified by meeting or not meeting the protein recommendation $(0.8 \mathrm{~g} / \mathrm{kg} / \mathrm{d})$ to compare demographics, diet quality with Healthy Eating Index2015, functional limitations, and other dietary intakes. Dietary recalls were collected using the multiple pass method. Data analyses were weighted to create a nationally-representative sample. Results: Dietary protein intakes were significantly lower in older age groups, with up to $46 \%$ of the oldest adults not meeting the protein intake recommendation. Participants consuming protein below the recommended intake level had significantly poorer diet quality across all age groups $(\mathrm{P}<0.01)$, however, overall diet quality was better in older adults. Those not meeting the protein recommendation were more likely to have intakes of other nutrients below recommended levels. Those below the protein recommendation had significantly more functional limitations across all age groups, while grip strength was significantly lower in those over 70 years old. Conclusion: Lower protein intakes, and lower diet quality and physical functioning are related in an aging population. Meeting the protein recommendation was linked to better overall diet quality and may be protective of lean mass; therefore, evaluation of individual characteristics which may affect protein intakes is crucial in supporting older adults to meet their protein needs.
\end{abstract}

Key words: Diet quality, protein intakes, physical limitations.

\section{Introduction}

Diet and nutrition play important roles in supporting healthful aging. Optimal nutrient intakes, especially dietary protein, are critically important for older adults as aging is associated with sarcopenia, a gradual and progressive decline in muscle mass, strength, and endurance (1). Sarcopenia can develop as early as 40 years of age and progresses considerably over the remainder of one's life, resulting in a $50 \%$ or greater loss of muscle strength. In older adults, sarcopenia contributes to increased risks of falls and fracture and lower quality of life (2). Therefore, meeting protein as well as other nutrient needs is imperative in maintaining lean body mass and for preserving strength and functional abilities in aging $(3,4)$.

Prior assessments of age-related differences in protein intakes show that protein consumption was greatest in adults aged 19-30 years (mean $91 \mathrm{~g}$ per day), but lowest for older adults with mean protein intakes of $66 \mathrm{~g}$ per day (5). In general, older adults are consuming less food, which contributes to insufficient amounts of dietary protein and energy $(6,7)$. Several factors influence protein intakes in older adults, including reduced energy needs, genetic predispositions to low appetite, age- and disease-related anorexia, physical and mental disabilities that limit acquiring and preparing food, change in food preference, dysphagia, dental issues, and food insecurity due to financial and social limitations (6,

Received October 24, 2018

Accepted for publication November 15, 2018
8). However, there remains a paucity of data regarding the proportion of older adults meeting recommended protein intake levels how protein intakes relate to overall diet quality and physical functioning. This is increasingly relevant as quality of life in aging is an important consideration.

While many are not meeting the current protein recommendation, several factors contribute to greater protein needs in older adults, suggesting those with lower protein intakes are even further away from optimal intakes. Body composition and lifestyle changes and comorbidities (9-12), as well as insulin resistance which may drive a decreased sensitivity to dietary amino acids (13), and may all result in older people requiring more than the recommended protein level. From a physiological perspective, older adults may develop anabolic resistance, a reduced muscle protein synthesis rate response to protein intake (14). Furthermore, prolonged disuse of muscles and increased sedentary behavior could contribute to muscle atrophy among older adults (8, 14). Apart from low grade chronic inflammation associated with aging (15), chronic illness further elevates inflammation, especially for those with chronic obstructive pulmonary disease (COPD), chronic kidney disease, or heart failure, all of which require greater protein intakes (8). If dietary intakes of protein remain below the recommended intake with greater protein needs during aging, over time these could manifest as physical functional limitations. Understanding age-related Published online February 19, 2019, http://dx.doi.org/10.1007/s12603-019-1174-1 


\section{THE JOURNAL OF NUTRITION, HEALTH \& AGINGC}

differences in intakes could be pivotal for targeted nutritional interventions to promote optimal health outcomes in aging. Therefore, the purpose of this study was to examine protein intakes and associated dietary patterns relative to the protein intake recommendations and assess differences in functional limitations among a nationally representative sample of older aged adults.

\section{Methods}

\section{Sample Population}

Data from 11,680 adults over 51 years old from the 20052014 National Health and Nutrition Examination Survey (NHANES) were utilized to examine protein intakes and associated dietary factors. NHANES collected data from the non-institutionalized population using a multistage stratified sampling technique to select participants. Demographic characteristics including age, gender, race, ethnicity, marital status, education level, and household income were obtained during in-home interviews. Physical and dietary measures were collected during visits to the mobile examination center. The National Center for Health Statistics' Research Ethics Review Board reviewed and approved all data collection protocols.

\section{Dietary Quality and Patterns Measures}

Dietary intakes were collected using the automated multiple pass method, which aims to collect foods and beverages consumed from midnight to midnight in the previous day by trained interviewers. Nutrient and MyPlate equivalent intakes were estimated by the US Department of Agriculture's Food Surveys Research Group using the Food and Nutrients Database for Dietary Studies (16) and Food Pyramid Equivalents Database (17), respectively. To account for age-related differences in energy intakes, energy-adjusted nutrients were computed and presented as nutrient intakes per 1,000 kcal. Nutrient intakes were classified as above or below the estimated average requirement (EAR) or adequate intake (AI) from the day of intake (18). Meal skipping was categorized based the participants reporting of foods or beverages based from selfidentification of the meal occasion (breakfast, lunch, dinner).

Total protein intakes and measured body weight were used to classify participants as being above or below the individual dietary protein intake recommendation of $0.8 \mathrm{~g} /$ $\mathrm{kg} / \mathrm{d}$. Differences in protein intakes from the recommendations were computed as the difference of intakes from recommended intakes.

To assess overall diet quality, the Healthy Eating Index (HEI) 2015 (19) was computed to assess intakes related to the 2015-2020 Dietary Guidelines for Americans (20). Higher scores on each of the 13 subscales are indicative of better diet quality, with the total scale ranging from 0-100, with higher scores denoting better diet quality.

\section{Physical F unctioning}

Physical functioning was assessed (yes/no) with the 19-item physical functioning questionnaire during an in-home interview to assess the participant's level of disability. Physical functioning items included fine motor limitations (using a fork, knife, drinking from a cup, grasping small objects), gross motor limitations (preparing meals, walking and standing for long periods), and social limitations (going out to movies, attending a social event). Isometric grip strength $(\mathrm{kg})$ was assessed with a hand grip dynanamometer. Grip strength was determined by summing the average values of grip strength for both hands.

\section{Analyses}

Data from adults aged 51 years and older were categorized into 51-60 years, 61-70 years, and 71 years and older for analysis. Adults were then stratified by either meeting or not the recommended $0.8 \mathrm{~g}$ of protein $/ \mathrm{kg}$ of body weight $/ \mathrm{d}(0.8 \mathrm{~g} / \mathrm{kg} / \mathrm{d})$ of protein to compare demographic characteristics, overall diet quality, nutrient intakes, physical functioning, and grip strength.

NHANES data were imported into SPSS Complex Samples (version 24, IBM SPPS Inc., Chicago, IL) for statistical analyses and to produce nationally representative estimates with statistically appropriate standard errors. Data are presented as means and standard errors or unweighted counts and weighted population percent for categorical data. Analysis of covariance for protein intakes and HEI scores were controlled for race/ ethnicity, gender, marital status, and percent of the federal poverty rate.

\section{Demographics}

\section{Results}

Complete dietary intake and anthropometric data from adults aged 51 years and older were categorized into 51-60 years $(n=4,016), 61-70$ years $(n=3,854)$, and 71 years and older $(n=3,810)$ were included in this analysis (Table 1). Across all age categories, males (69\% of 51-60 year old, $63 \%$ of $61-70$ year old, and $58 \%$ of those over 70 years old) are more likely to meet recommended protein intakes compared to females (55\% of 51-60 year old's, 52\% of 61-70 year old, and $50 \%$ of those over 70 years old). Non-Hispanic blacks and those who were single, divorced, or widowed were least likely to meet recommended protein intakes across all age categories.

\section{Dietary Intakes}

Across all age groups, those not meeting the recommended protein intake had significantly lower intakes of total energy $(\mathrm{P}<0.001)$ and energy adjusted protein $(\mathrm{P}<0.001$, Table 2$)$. Those not meeting the recommended protein intake requirement also had a significantly lower energy adjusted consumption of carbohydrates, total fat, saturated fat, monounsaturated fat, choline, vitamin $\mathrm{C}$, phosphorus, zinc, and selenium per 1,000 kcal across all age groups. However, only $10 \%$ of adults 51-60 years old, $12 \%$ of adults 61-70 years old, and $13 \%$ of adults over 71 years old below the protein intake recommendation also 


\section{LOW DIETARY PROTEIN INTAKES AND ASSOCIATED DIETARY PATTERNS AND FUNCTIONAL LIMITATIONS}

Table 1

Personal and demographic characteristics in US older adults, stratified by intakes above or below protein intake recommendations from the dietary recalla

\begin{tabular}{|c|c|c|c|c|c|c|c|}
\hline \multirow[b]{2}{*}{ Characteristic } & \multirow[b]{2}{*}{ Category } & \multicolumn{2}{|c|}{$51-60 \mathrm{yrs}$} & \multicolumn{2}{|c|}{$61-70 \mathrm{yrs}$} & \multicolumn{2}{|c|}{$>70 \mathrm{yrs}$} \\
\hline & & $\begin{array}{l}\text { Below protein } \\
\text { recommendation }\end{array}$ & $\begin{array}{c}\text { Met protein } \\
\text { recommendation }\end{array}$ & $\begin{array}{l}\text { Below protein } \\
\text { recommendation }\end{array}$ & $\begin{array}{c}\text { Met protein } \\
\text { recommendation }\end{array}$ & $\begin{array}{l}\text { Below protein } \\
\text { recommendation }\end{array}$ & $\begin{array}{c}\text { Met protein } \\
\text { recommendation }\end{array}$ \\
\hline & & \multicolumn{6}{|c|}{ n (\%) } \\
\hline \multirow[t]{2}{*}{ Gender } & Male & $646(30.6 \%)$ & $1340(69.4 \%)$ & $770(36.6 \%)$ & $1145(63.4 \%)$ & $842(41.7 \%)$ & $1051(58.3 \%)$ \\
\hline & Female & $998(45 \%)$ & $1032(55 \%)$ & $1011(48.4 \%)$ & $928(51.6 \%)$ & $999(50.3 \%)$ & $918(49.7 \%)$ \\
\hline \multirow[t]{5}{*}{ Race/Ethnicity } & Mexican American & $223(36.4 \%)$ & $374(63.6 \%)$ & $269(42.8 \%)$ & $356(57.2 \%)$ & $135(49.7 \%)$ & $133(50.3 \%)$ \\
\hline & Other Hispanic & $152(39.4 \%)$ & $237(60.6 \%)$ & $182(42.5 \%)$ & $211(57.5 \%)$ & $101(45.8 \%)$ & $97(54.2 \%)$ \\
\hline & Non-Hispanic White & $657(36.5 \%)$ & $1037(63.5 \%)$ & $696(41.4 \%)$ & $922(58.6 \%)$ & $1202(45.7 \%)$ & $1385(54.3 \%)$ \\
\hline & Non-Hispanic Black & $518(52.9 \%)$ & $485(47.1 \%)$ & $553(57.9 \%)$ & $426(42.1 \%)$ & $336(57.4 \%)$ & $247(42.6 \%)$ \\
\hline & Other or Multiracial & $94(27.6 \%)$ & $239(72.4 \%)$ & $81(38.1 \%)$ & $158(61.9 \%)$ & $67(42.5 \%)$ & $107(57.5 \%)$ \\
\hline \multirow[t]{2}{*}{ Marital Status } & Single/Divorced/Widowed & $683(40.8 \%)$ & $830(59.2 \%)$ & $744(47.4 \%)$ & $728(52.6 \%)$ & $862(45.8 \%)$ & $919(54.2 \%)$ \\
\hline & Married/Living as Married & $961(36.6 \%)$ & $1542(63.4 \%)$ & $1037(40.8 \%)$ & $1345(59.2 \%)$ & $979(47.4 \%)$ & $1050(52.6 \%)$ \\
\hline \multirow{5}{*}{$\begin{array}{l}\text { Highest Education Com- } \\
\text { pletion }\end{array}$} & $<9$ th grade & $188(37.5 \%)$ & $275(62.5 \%)$ & $293(49.4 \%)$ & $304(50.6 \%)$ & $380(56 \%)$ & $313(44 \%)$ \\
\hline & 9-11th grade & $256(43.5 \%)$ & $316(56.5 \%)$ & $310(50.9 \%)$ & $283(49.1 \%)$ & $320(50.3 \%)$ & $292(49.7 \%)$ \\
\hline & HS/GED & $398(42.6 \%)$ & $532(57.4 \%)$ & $428(46.3 \%)$ & $457(53.7 \%)$ & $468(48.2 \%)$ & $489(51.8 \%)$ \\
\hline & Some college or Associate's degree & $468(40.9 \%)$ & $643(59.1 \%)$ & $467(47 \%)$ & $542(53 \%)$ & $400(46.5 \%)$ & $452(53.5 \%)$ \\
\hline & College grad & $333(29.7 \%)$ & $605(70.3 \%)$ & $283(31.8 \%)$ & $485(68.2 \%)$ & $268(36.4 \%)$ & $418(63.6 \%)$ \\
\hline \multirow{4}{*}{$\begin{array}{l}\text { Meal consumption (\% } \\
\text { consuming) }\end{array}$} & Breakfast & $1386(86.8 \%)$ & $2137(91.5 \%)$ & $1555(87.9 \%)$ & $1917(94.2 \%)$ & $1705(94.4 \%)$ & $1904(97.1 \%)$ \\
\hline & Lunch & $1117(71.7 \%)$ & $1861(84.3 \%)$ & $1182(73.4 \%)$ & $1583(81.9 \%)$ & $1250(71.6 \%)$ & $1526(81.3 \%)$ \\
\hline & Dinner & $1426(90 \%)$ & $2175(94.9 \%)$ & $1525(90.9 \%)$ & $1909(96 \%)$ & $1614(90.4 \%)$ & $1857(95.9 \%)$ \\
\hline & Snack & $1563(96.9 \%)$ & $2275(97.3 \%)$ & $1672(96.1 \%)$ & $1969(96.5 \%)$ & $1697(92.9 \%)$ & $1848(94.1 \%)$ \\
\hline \multirow[t]{4}{*}{ Number of meals reported } & 1 meal & $165(7.6 \%)$ & $99(3 \%)$ & $155(6.3 \%)$ & $75(2.3 \%)$ & $111(3.7 \%)$ & $22(0.6 \%)$ \\
\hline & 2 meals & $646(35 \%)$ & $730(22.8 \%)$ & $726(33.7 \%)$ & $651(23.2 \%)$ & $714(35.8 \%)$ & $573(24.4 \%)$ \\
\hline & 3 meals & $824(57 \%)$ & $1538(74 \%)$ & $885(59.5 \%)$ & $1344(74.5 \%)$ & $1010(60.4 \%)$ & $1373(74.9 \%)$ \\
\hline & & \multicolumn{6}{|c|}{ Mean (SE) } \\
\hline Poverty-Income Ratio & & $3.0(0.09)$ & $3.6(0.06)$ & $3.0(0.06)$ & $3.4(0.06)$ & $2.5(0.05)$ & $2.8(0.06)$ \\
\hline Body Mass Index $\left(\mathrm{kg} / \mathrm{m}^{2}\right)$ & & $32.3(0.27)$ & $27.9(0.18)$ & $32(0.22)$ & $27.7(0.18)$ & $30.0(0.19)$ & $26.3(0.12)$ \\
\hline Weight (kg) & & $91.3(0.8)$ & $80.4(0.64)$ & $89.4(0.71)$ & $78.5(0.6)$ & $80.5(0.55)$ & $71.3(0.41)$ \\
\hline
\end{tabular}

a. Protein intake recommendations computed as $0.8 \mathrm{~g}$ of dietary protein per kilogram of body weight.

had carbohydrates intakes below the AI (Table 3). Those not meeting the protein intake recommendation were also below the EAR for zinc, selenium, vitamin E, vitamin C, and vitamin D intakes across all age categories (Table 3 ). In addition, only $11 \%$ of adults $51-60$ and $61-70$ years old, and $13 \%$ of adults over 71 years old not meeting the protein recommendation were below the EAR for iron.

Skipping meal frequencies for breakfast, lunch and dinner were higher across each age group for adults who did not meet the protein intake recommendation. Approximately $74 \%$ of adults meeting the protein recommendation reported consuming three meals per day, compared to the $40-43 \%$ of those who did not meet the recommendation reporting fewer than three meals per day.

\section{Diet Quality}

Across all age categories, adults not meeting the recommended protein intake had significantly lower total HEI scores (Table 4). Those not meeting protein recommendations had scored significantly less for greens and beans $(\mathrm{P}<0.001)$, dairy $(\mathrm{P}<0.001)$, total protein foods $(\mathrm{P}<0.001$ for all age categories), seafood and plant protein foods $(\mathrm{P}<0.001)$, refined grains $(\mathrm{P}=0.022$ for $51-60$ year old's, $\mathrm{P}=0.005$ for $61-70$ year old's, $\mathrm{P}<0.001$ for $>70$ year old's) and added sugars ( $\mathrm{P}<0.001$ for all age categories), however, the whole grain score was only significantly lower for those not meeting the protein recommendation in the 61-70 year old's, although whole grain intakes were low overall (highest mean score was 3.5/10 in the over 70 age group). Notably, adults aged 51-60 years old not meeting protein recommendations had significantly lower diet quality scores for sodium, which as a moderation subscale indicates they consumed more of this nutrient $(\mathrm{P}<0.001)$. Adults between 61-70 years old not meeting the protein recommendation had significantly lower diet quality scores for total fruit $(\mathrm{P}=0.007)$. 
Table 2

Differences in energy and energy-adjusted nutrient intakes across age groups for those who were below or met the protein intake recommendation from the 2005-2014 National Health and Nutrition Examination Survey (NHANES) a,b,c

\begin{tabular}{|c|c|c|c|c|c|c|c|c|c|}
\hline & \multicolumn{3}{|c|}{$51-60 \mathrm{yr}$} & \multicolumn{3}{|c|}{$61-70 \mathrm{yr}$} & \multicolumn{3}{|c|}{$>70 \mathrm{yr}$} \\
\hline & $\begin{array}{l}\text { Below protein } \\
\text { recommendation }\end{array}$ & $\begin{array}{c}\text { Met protein } \\
\text { recommendation }\end{array}$ & $\mathbf{P}$ & $\begin{array}{l}\text { Below protein } \\
\text { recommendation }\end{array}$ & $\begin{array}{c}\text { Met protein } \\
\text { recommendation }\end{array}$ & $\mathbf{P}$ & $\begin{array}{l}\text { Below protein } \\
\text { recommendation }\end{array}$ & $\begin{array}{c}\text { Met protein } \\
\text { recommendation }\end{array}$ & $\mathbf{P}$ \\
\hline Energy (kcal) & $1630(24)$ & $2420(23)$ & $<0.001$ & $1501(17)$ & $2213(22)$ & $<0.001$ & $1356(18)$ & $1994(22)$ & $<0.001$ \\
\hline Protein, total (g) & $54.3(0.8)$ & $100.5(1.1)$ & $<0.001$ & $51.0(0.7)$ & $93.0(0.8)$ & $<0.001$ & $47.4(0.6)$ & $84.6(0.8)$ & $<0.001$ \\
\hline \multicolumn{10}{|l|}{ Energy-adjusted intakes } \\
\hline Protein (g) & $35.0(0.4)$ & $43.4(0.4)$ & $<0.001$ & $35.8(0.4)$ & $43.8(0.4)$ & $<0.001$ & $36.5(0.3)$ & $44.2(0.3)$ & $<0.001$ \\
\hline Carbohydrate (g) & $128(1.0)$ & $115(0.9)$ & $<0.001$ & $128(1.0)$ & $117(0.8)$ & $<0.001$ & $133(0.8)$ & $122(0.7)$ & $<0.001$ \\
\hline Dietary fiber (g) & $8.6(0.2)$ & $8.4(0.2)$ & 0.564 & $9.4(0.2)$ & $9.3(0.2)$ & 0.361 & $9.8(0.2)$ & $9.7(0.2)$ & 0.342 \\
\hline Total fat (g) & $36.2(0.4)$ & $38.8(0.3)$ & $<0.001$ & $36.9(0.3)$ & $38.1(0.3)$ & 0.004 & $35.9(0.3)$ & $37.3(0.3)$ & $<0.001$ \\
\hline Saturated fat (g) & $11.3(0.2)$ & $12.4(0.1)$ & $<0.001$ & $11.7(0.2)$ & $12.2(0.1)$ & 0.014 & $11.6(0.1)$ & $11.9(0.2)$ & 0.160 \\
\hline Monounsaturated fat $(\mathrm{g})$ & $12.9(0.2)$ & $14.0(0.1)$ & $<0.001$ & $13.3(0.2)$ & $13.7(0.1)$ & 0.036 & $12.8(0.1)$ & $13.6(0.1)$ & $<0.001$ \\
\hline Polyunsaturated fat (g) & $8.7(0.2)$ & $8.9(0.1)$ & 0.246 & $8.7(0.1)$ & $8.7(0.1)$ & 0.672 & $8.3(0.1)$ & $8.6(0.1)$ & 0.158 \\
\hline Vitamin A, RAE $(\mu \mathrm{g})$ & $311(15.9)$ & $339(10.6)$ & 0.076 & $358(12.0)$ & $381(26.4)$ & 0.413 & $405(14.7)$ & $402(10.4)$ & 0.854 \\
\hline Folate ( $\mu \mathrm{g}$ DFE) & $268(6.3)$ & $257(5.5)$ & 0.239 & $273(4.8)$ & $268(5.5)$ & 0.602 & $308(5.9)$ & $286(5.9)$ & 0.005 \\
\hline Choline (mg) & $153(3.1)$ & $171(1.9)$ & $<0.001$ & $161(3.0)$ & $183(2.5)$ & $<0.001$ & $165(2.3)$ & $184(1.9)$ & $<0.001$ \\
\hline Vitamin B12 $(\mu \mathrm{g})$ & $2.4(0.1)$ & $2.5(0.1)$ & 0.456 & $2.4(0.1)$ & $3.2(0.3)$ & 0.019 & $2.6(0.1)$ & $3.0(0.1)$ & 0.003 \\
\hline Vitamin C (mg) & $49.4(2.8)$ & $43.0(1.3)$ & 0.040 & $51.6(1.7)$ & $45.2(1.9)$ & 0.012 & $57.5(2.0)$ & $50.9(1.6)$ & 0.005 \\
\hline Vitamin $\mathrm{D}(\mu \mathrm{g})$ & $2.1(0.2)$ & $2.4(0.1)$ & 0.083 & $2.2(0.1)$ & $2.6(0.1)$ & 0.004 & $2.6(0.1)$ & $3.2(0.1)$ & $<0.001$ \\
\hline Vitamin $\mathrm{K}(\mu \mathrm{g})$ & $62.7(3.7)$ & $72.6(4.7)$ & 0.073 & $67.8(3.0)$ & $66.4(3.1)$ & 0.706 & $69.3(3.9)$ & $71.1(3.3)$ & 0.616 \\
\hline Calcium (mg) & $432(7.8)$ & $458(7.3)$ & 0.023 & $466(9.7)$ & $468(6.2)$ & 0.819 & $479(7.5)$ & $497(5.6)$ & 0.031 \\
\hline Phosphorus (mg) & $601(6.9)$ & $680(5.7)$ & $<0.001$ & $636(7.0)$ & $702(4.9)$ & $<0.001$ & $641(5.0)$ & $715(5.3)$ & $<0.001$ \\
\hline Magnesium (mg) & $150(2.6)$ & $153(1.8)$ & 0.315 & $158(2.5)$ & $160(2)$ & 0.501 & $158(2.2)$ & $163(2.0)$ & 0.033 \\
\hline Iron (mg) & $7.3(0.2)$ & $7.4(0.1)$ & 0.928 & $7.7(0.1)$ & $7.7(0.1)$ & 0.930 & $8.6(0.1)$ & $8.4(0.1)$ & 0.163 \\
\hline Zinc (mg) & $4.9(0.1)$ & $5.9(0.1)$ & $<0.001$ & $5.1(0.1)$ & $6.1(0.1)$ & $<0.001$ & $5.6(0.1)$ & $6.4(0.1)$ & $<0.001$ \\
\hline Copper (mg) & $0.7(0.02)$ & $0.7(0.01)$ & 0.586 & $0.7(0.01)$ & $0.8(0.05)$ & 0.230 & $0.7(0.02)$ & $0.7(0.01)$ & 0.971 \\
\hline Sodium (mg) & $1626(20)$ & $1731(23)$ & $<0.001$ & $1712(21)$ & $1727(20)$ & 0.597 & 1704 (18) & $1718(17)$ & 0.487 \\
\hline Potassium (mg) & $390(36)$ & $1372(16)$ & 0.655 & $1469(20)$ & $1442(15)$ & 0.341 & $1493(18)$ & $1515(17)$ & 0.273 \\
\hline Selenium $(\mu \mathrm{g})$ & $49.4(0.7)$ & $58.7(0.7)$ & $<0.001$ & $51.0(0.7)$ & $60.4(0.7)$ & $<0.001$ & $51.2(0.7)$ & $59.7(0.7)$ & $<0.001$ \\
\hline
\end{tabular}

\section{Functional Limitations}

Across all age categories, those not meeting the protein recommendation more commonly encountered physical limitations than those meeting the protein recommendation. Specifically, those below the protein intake recommendation were more likely to be limited when stooping, crouching or kneeling, standing or sitting for long periods, walking up 10 steps, preparing meals, and walking for a quarter mile. The prevalence of physical limitations for adults aged 51-60 years old including: sitting for long periods, getting in and out of bed, preparing meals, leisure activities at home, and using a fork, knife, and drinking from a cup was within $3 \%$ of the prevalence of these same limitations for the sample population over 71 years old. Adults across every age category had a higher prevalence of physical, mental, and social limitations than those meeting the protein recommendation, except for adults over 71 years old. Combined hand grip strength was not significantly different for those not meeting the protein recommendation for participants aged 51-60 and 61-70 years, but was significantly lower for participants over 70 years.

\section{Discussion}

The requirement for higher protein intake recommendations in the older population is being led by several experts in the field, both in the free living population $(8,11,13)$ and in hospitalized patients (21). This study adds to the body of evidence supporting an emphasis on protein intakes in aging. Protein intakes and associated dietary patterns in relation to demographic, anthropometric and functional characteristics were examined, among older adults in the United States. A considerable proportion of older adults $(31-50 \%)$ did not meet their protein recommendation $(0.8 \mathrm{~g} / \mathrm{kg} / \mathrm{d})$ on the day of their NHANES dietary assessment. This contradicts the common 


\section{LOW DIETARY PROTEIN INTAKES AND ASSOCIATED DIETARY PATTERNS AND FUNCTIONAL LIMITATIONS}

Table 3

Proportion below the Estimated Average Requirement or Adequate Intakes across Age Categories and Meeting the Protein

Recommendation $^{\mathrm{a}}$

\begin{tabular}{|c|c|c|c|c|c|c|}
\hline & \multicolumn{2}{|c|}{$51-60 \mathrm{yrs}$} & \multicolumn{2}{|c|}{$61-70 \mathrm{yrs}$} & \multicolumn{2}{|c|}{$>70 \mathrm{yrs}$} \\
\hline & $\begin{array}{l}\text { Below Protein } \\
\text { recommedation }\end{array}$ & $\begin{array}{c}\text { Met Protein } \\
\text { recommedation }\end{array}$ & $\begin{array}{l}\text { Below Protein } \\
\text { recommedation }\end{array}$ & $\begin{array}{c}\text { Met Protein } \\
\text { recommedation }\end{array}$ & $\begin{array}{l}\text { Below Protein } \\
\text { recomendation }\end{array}$ & $\begin{array}{l}\text { Met Protein } \\
\text { recommedation }\end{array}$ \\
\hline Carbohydrate & $185(10.2 \%)$ & $64(2.5 \%)$ & $236(11.9 \%)$ & $49(2.4 \%)$ & $251(12.9 \%)$ & $45(1.9 \%)$ \\
\hline Fiber & $1504(90.9 \%)$ & $1814(76.0 \%)$ & $1665(92.5 \%)$ & $1586(76.7 \%)$ & $1738(94.1 \%)$ & $1603(79.8 \%)$ \\
\hline Thiamin & $663(35.1 \%)$ & $246(9.1 \%)$ & $752(36.2 \%)$ & $213(9.1 \%)$ & $758(39.0 \%)$ & $198(9.1 \%)$ \\
\hline Riboflavin & $414(17.8 \%)$ & $90(2.6 \%)$ & $481(19.7 \%)$ & $97(2.7 \%)$ & $447(20 \%)$ & $66(2.7 \%)$ \\
\hline Niacin & $432(21.3 \%)$ & $45(1.0 \%)$ & $538(25.5 \%)$ & $50(2.9 \%)$ & $607(30.5 \%)$ & $64(3.3 \%)$ \\
\hline Vitamin B6 & $984(54.9 \%)$ & $365(14.2 \%)$ & $1097(57.7 \%)$ & $352(15.9 \%)$ & $1116(57.5 \%)$ & $396(19.8 \%)$ \\
\hline Folate & $772(41.9 \%)$ & $432(17.2 \%)$ & $887(45.8 \%)$ & $388(17.7 \%)$ & $906(47.2 \%)$ & $422(20.7 \%)$ \\
\hline Vitamin B12 & $702(38.6 \%)$ & $291(11.2 \%)$ & $721(36.4 \%)$ & $271(11.3 \%)$ & $699(35.3 \%)$ & $185(8.3 \%)$ \\
\hline Vitamin C & $1062(63.6 \%)$ & $1212(49.5 \%)$ & $1117(62.3 \%)$ & $1010(48.0 \%)$ & $1092(57.6 \%)$ & $913(45.0 \%)$ \\
\hline Choline & $1590(96.2 \%)$ & $1762(76.2 \%)$ & $1739(97.8 \%)$ & $1599(77.5 \%)$ & $1819(98.6 \%)$ & $1666(84.2 \%)$ \\
\hline Vitamin A & $1206(68.9 \%)$ & $1171(42.0 \%)$ & $1251(66.3 \%)$ & $994(42.6 \%)$ & $1246(64.3 \%)$ & $807(37.7 \%)$ \\
\hline Vitamin D & $1370(96.4 \%)$ & $1710(84.5 \%)$ & $1463(97.0 \%)$ & $1481(85.5 \%)$ & $1475(96.7 \%)$ & $1369(84.8 \%)$ \\
\hline Vitamin E & $1541(93.0 \%)$ & $1835(74.0 \%)$ & $1670(92.1 \%)$ & $1659(77.5 \%)$ & $1754(94.0 \%)$ & $1650(83.5 \%)$ \\
\hline Vitamin $K$ & $1288(75.5 \%)$ & $1526(59.8 \%)$ & $1422(76.4 \%)$ & $1325(60.4 \%)$ & $1512(80.5 \%)$ & $1325(64.8 \%)$ \\
\hline Calcium & $1337(80.5 \%)$ & $1105(43.5 \%)$ & $1430(77.1 \%)$ & $1060(47.1 \%)$ & $1625(87.7 \%)$ & $1161(57.5 \%)$ \\
\hline Phosphorus & $316(15.0 \%)$ & $7(0.2 \%)$ & $355(17.1 \%)$ & $8(0.2 \%)$ & $425(21.9 \%)$ & $13(0.7 \%)$ \\
\hline Magnesium & $1364(81.2 \%)$ & $1046(39.6 \%)$ & $1532(82.9 \%)$ & $984(43.5 \%)$ & $1661(88.3 \%)$ & 1075 (51.9\%) \\
\hline Iron & $214(10.8 \%)$ & $20(0.4 \%)$ & $258(10.7 \%)$ & $21(0.6 \%)$ & $278(13.3 \%)$ & $24(1.4 \%)$ \\
\hline Zinc & $1045(58.7 \%)$ & $387(13.4 \%)$ & $1171(60.2 \%)$ & $383(15.2 \%)$ & $1291(66.4 \%)$ & $408(17.4 \%)$ \\
\hline Copper & $543(29.1 \%)$ & $146(4.4 \%)$ & $626(31.7 \%)$ & $127(5.1 \%)$ & $686(34.6 \%)$ & $157(7.4 \%)$ \\
\hline Selenium & $337(19.1 \%)$ & $12(0.5 \%)$ & $390(19.9 \%)$ & $11(0.6 \%)$ & $475(24.7 \%)$ & $23(1.2 \%)$ \\
\hline
\end{tabular}

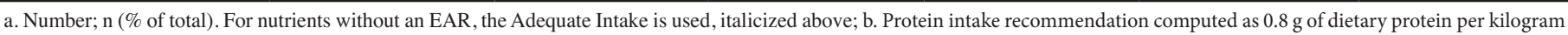
of body weight

perception that Americans are usually meeting or exceeding the $0.8 \mathrm{~g} / \mathrm{kg} / \mathrm{d}$ protein recommendation. In the most recent study, Berryman and colleagues (22) suggest that protein is consumed in excess of the recommendation in the majority of people aged 2 years or older. These estimates were statistically adjusted for assumed intrapersonal variability and used $0.8 \mathrm{~g} /$ $\mathrm{kg} / \mathrm{d}$ of protein for ideal body weight to determine protein intake recommendations. These data suggest that $7-19 \%$ of older adults did not meet protein intake recommendations, nevertheless, this assessment of unadjusted protein intakes per ideal body weight suggests that the rate of low protein intakes on a given day is higher, nearly one third of older adults. The data reported here represent a single day's intake, which cannot be assumed to be the usual intake pattern, however, if these nationally representative data reflect the broader pattern of protein intakes, it indicates further efforts to optimize dietary quality and protein intakes for aging are required.

Prevalence data within this analysis suggests that older age groups are progressively less likely to meet protein recommendations, the age range which corresponds with when sarcopenia becomes more prevalent (23), suggesting habitually moderate protein intakes may contribute to sarcopenia (11). If protein needs for older people exceed the current recommendation of $0.8 \mathrm{~g} / \mathrm{kg}$ and over one third are not meeting that standard, these data suggest that far fewer older adults would be meeting the proposed higher levels (1-1.2 g/kg/d) needed to meet the demands to promote healthful aging (24). If the recommendations are increased, specific strategies will be needed to support older adults consuming diets, especially for those already below the existing $0.8 \mathrm{~g} / \mathrm{kg}$.

A major challenge to increasing nutrient intakes in aging is the appetite decline associated with age. This phenomenon has been attributed to numerous factors, such as poor dentition, reduced sense of taste and smell, delayed gastric emptying and depression, all of which are conditions prevalent among older adults (25-29). The anorexia of aging is well established, and is reported to affect between 15 and $30 \%$ of aging adults $(30,31)$. Apart from pharmacological appetite stimulants, addressing these issues may help to enhance appetite among older adults. Other approaches to increase nutrient intake in the older population include, improving oral health, enhance the sensory attributes of foods (flavor and smells) with extra 


\section{THE JOURNAL OF NUTRITION, HEALTH \& AGINGC}

Table 4

Differences in Healthy Eating Index 2015 scores across age groups and in those below or meeting the protein intake recommendation ${ }^{\mathrm{a}, \mathrm{b}}$

\begin{tabular}{|c|c|c|c|c|c|c|c|c|c|}
\hline \multirow[b]{2}{*}{ HEI-2015 Score (score range) } & \multicolumn{3}{|c|}{$51-60 \mathrm{yrs}$} & \multicolumn{3}{|c|}{$61-70 \mathrm{yrs}$} & \multicolumn{3}{|c|}{$>70 \mathrm{yrs}$} \\
\hline & $\begin{array}{l}\text { Below protein } \\
\text { recommendation }\end{array}$ & $\begin{array}{c}\text { Met protein } \\
\text { recommendation }\end{array}$ & $\mathbf{P}$ & $\begin{array}{l}\text { Below protein } \\
\text { recommendation }\end{array}$ & $\begin{array}{c}\text { Met protein } \\
\text { recommendation }\end{array}$ & $\mathbf{P}$ & $\begin{array}{l}\text { Below protein } \\
\text { recommendation }\end{array}$ & $\begin{array}{l}\text { Met protein } \\
\text { recommendation }\end{array}$ & $\mathbf{P}$ \\
\hline Total Fruit (0-5) & $2.3(0.11)$ & $2.2(0.06)$ & 0.211 & $2.5(0.08)$ & $2.5(0.07)$ & 0.512 & $3.0(0.07)$ & $2.9(0.07)$ & 0.078 \\
\hline Whole Fruit (0-5) & $2.3(0.10)$ & $2.3(0.07)$ & 0.691 & $2.4(0.07)$ & $2.7(0.07)$ & 0.007 & $2.8(0.07)$ & $2.9(0.06)$ & 0.260 \\
\hline Total Vegetables (0-5) & $3.1(0.08)$ & $3.3(0.05)$ & 0.025 & $3.3(0.06)$ & $3.4(0.05)$ & 0.092 & $3.1(0.06)$ & $3.4(0.05)$ & 0.003 \\
\hline Greens \& Beans (0-5) & $1.3(0.09)$ & $1.8(0.07)$ & $<0.001$ & $1.5(0.09)$ & $2.0(0.08)$ & $<0.001$ & $1.3(0.06)$ & $1.8(0.07)$ & $<0.001$ \\
\hline Whole Grains (0-10) & $2.6(0.14)$ & $2.7(0.13)$ & 0.682 & $2.8(0.13)$ & $3.1(0.12)$ & 0.030 & $3.4(0.13)$ & $3.5(0.11)$ & 0.292 \\
\hline Dairy (0-10) & $4.2(0.15)$ & $5.0(0.11)$ & $<0.001$ & $4.4(0.12)$ & $5.2(0.09)$ & $<0.001$ & $4.7(0.1)$ & $5.4(0.09)$ & $<0.001$ \\
\hline Protein Foods (0-5) & $4.0(0.06)$ & $4.6(0.03)$ & $<0.001$ & $3.9(0.05)$ & $4.6(0.04)$ & $<0.001$ & $3.9(0.05)$ & $4.6(0.04)$ & $<0.001$ \\
\hline Seafood \& Plant Proteins (0-5) & $2.2(0.08)$ & $2.6(0.07)$ & $<0.001$ & $2.4(0.10)$ & $2.9(0.08)$ & $<0.001$ & $2.0(0.06)$ & $2.8(0.08)$ & $<0.001$ \\
\hline Fatty Acids (0-10) & $5.6(0.15)$ & $5.3(0.08)$ & 0.055 & $5.6(0.13)$ & $5.3(0.12)$ & 0.093 & $5.12(0.12)$ & $5.3(0.13)$ & 0.401 \\
\hline Refined Grains ${ }^{c}(0-10)$ & $6.2(0.15)$ & $6.7(0.14)$ & 0.022 & $6.1(0.12)$ & $6.6(0.14)$ & 0.005 & $6.1(0.11)$ & $6.8(0.10)$ & $<0.001$ \\
\hline Sodium $^{\mathrm{c}}(0-10)$ & $4.9(0.14)$ & $4.2(0.11)$ & $<0.001$ & $4.4(0.14)$ & $4.1(0.12)$ & 0.146 & $4.5(0.12)$ & $4.3(0.11)$ & 0.178 \\
\hline Added Sugars $^{c}(0-10)$ & $6.2(0.19)$ & $7.1(0.10)$ & $<0.001$ & $6.7(0.12)$ & $7.6(0.09)$ & $<0.001$ & $6.9(0.11)$ & $7.7(0.09)$ & $<0.001$ \\
\hline Saturated Fat ${ }^{\mathrm{c}}(0-10)$ & $6.7(0.14)$ & $5.9(0.11)$ & $<0.001$ & $6.4(0.11)$ & $6.1(0.11)$ & 0.036 & $6.5(0.12)$ & $6.3(0.13)$ & 0.177 \\
\hline Total HEI Score $(0-100)$ & $51.4(0.68)$ & $53.5(0.41)$ & 0.005 & $52.2(0.53)$ & $55.9(0.53)$ & $<0.001$ & $53.3(0.48)$ & $57.6(0.56)$ & $<0.001$ \\
\hline
\end{tabular}

Higher scores for scales related to moderation represent lower intakes.

seasonings, introducing variety of foods at mealtimes, utilizing colored cutlery and plating options, increasing physical activity, and enriching foods served with supplemental calories $(27,28$, 32). The complexity of appetite in the older population may make increasing protein challenging, but it seems a combination of tactics may be required at the individual level.

Adults not meeting the protein recommendation were more likely to have lower intakes of several nutrients, including fiber, thiamin, niacin, vitamin B6, folate, choline, vitamin C, vitamin B12, vitamin A, vitamin D, vitamin E, vitamin K, zinc, calcium, phosphorus, magnesium, iron, copper, and selenium. The 20152020 Dietary Guidelines for Americans recognizes that within the context of a poorer quality diet (low in vegetables, fruits, whole grains, and dairy) certain nutrients are consumed below the EAR or AI level. These are referred to as nutrients of public health concern and include fiber, choline, vitamin C, vitamin A, vitamin $\mathrm{D}$, vitamin $\mathrm{E}$, potassium, calcium, magnesium and iron. Potassium is also a nutrient of public health concern but it did not feature in these analyses. Examining the function of each vitamin and mineral that was found to be lower in those not meeting the protein recommendation, in the context of healthy aging is beyond the scope of this paper, however, their physiological functions in human metabolism are well known; therefore, metabolic homeostasis may be affected with habitual insufficiencies of these nutrients with possible implications for aging outcomes. Of particular note dietary fiber is associated with many benefits, especially in reducing the risk for coronary heart disease (33); vitamin D inadequacy is associated with reduced mobility, and an increase in the risk for falls and fractures, and death from cardiovascular disease (34), and; zinc insufficiencies can result in lower zinc concentrations in immune cells and platelets and may cause dysfunctions in immunity, and reduce healing time (35), which could be troublesome for elderly populations. Overall, adults not meeting protein needs have much higher likelihood of lower micronutrient intakes (on the day of intake), and nutrient deficiencies, combined with a lower protein intake, in older adults may increase risks of common issues, such as falls, pressure sores, osteomalacia, osteoporosis, hip fractures, muscle weakness, and mortality $(27,31)$.

The current study found that diet quality (measured by HEI) was poorest in adults aged 51-60 years, compared to their older counterparts. This finding is in agreement with previous studies that found older adults had better quality diets than middle aged adults $(24,36-38)$; however, the mean HEI score in a sample of older adults (60 years and older) has been reported to be considerably higher (HEI: 66.6) than seen in this nationally representative study (39). However, these data were from earlier NHANES results (1999-2002) and used a slightly different coding system for the HEI score; although we expect no significant impact on the overall score using the revised coding. We hypothesize that age related differences related to habitual dietary patters, such as the frequencies of dining out and cooking meals, may contribute to the better diet quality in older adults compared to middle aged adults. Furthermore, older adults, may have consumed more wholesome diets, reflected in higher HEI scores, over their lifetime, which may have had long lasting effects, and those diets may have contributed to their longevity. The presence of low HEI scores, with increased prevalence of chronic diseases in the younger 


\section{LOW DIETARY PROTEIN INTAKES AND ASSOCIATED DIETARY PATTERNS AND FUNCTIONAL LIMITATIONS}

Table 5

Frequency of limitations and grip strength differences across age groups in those below or meeting the protein intake recommendation ${ }^{\mathrm{a}, \mathrm{b}}$

\begin{tabular}{|c|c|c|c|c|c|c|}
\hline \multirow[b]{2}{*}{ Limitations Experienced } & \multicolumn{2}{|c|}{$51-60 \mathrm{yrs}$} & \multicolumn{2}{|c|}{$61-70 \mathrm{yrs}$} & \multicolumn{2}{|c|}{$>70 \mathrm{yrs}$} \\
\hline & $\begin{array}{l}\text { Below protein } \\
\text { recommendation }\end{array}$ & $\begin{array}{l}\text { Met protein } \\
\text { recommendation }\end{array}$ & $\begin{array}{l}\text { Below protein } \\
\text { recommendation }\end{array}$ & $\begin{array}{l}\text { Met protein } \\
\text { recommendation }\end{array}$ & $\begin{array}{l}\text { Below protein } \\
\text { recommendation }\end{array}$ & $\begin{array}{l}\text { Met protein } \\
\text { recommendation }\end{array}$ \\
\hline & \multicolumn{6}{|c|}{$n$ (population \%) } \\
\hline Stooping, crouching, kneeling & $512(27.8 \%)$ & $427(16.5 \%)$ & $902(50.2 \%)$ & $754(33.9 \%)$ & $1054(58.3 \%)$ & $935(46.8 \%)$ \\
\hline Standing for long periods & $458(24.9 \%)$ & $403(16.1 \%)$ & $732(37.9 \%)$ & $615(25.6 \%)$ & $950(52.0 \%)$ & $833(41.4 \%)$ \\
\hline Push or pull large objects & $388(21.1 \%)$ & $353(14.0 \%)$ & $599(32.1 \%)$ & $501(22.4 \%)$ & $757(41.2 \%)$ & $666(32.9 \%)$ \\
\hline Sitting for long periods & $336(16.7 \%)$ & $290(11.2 \%)$ & $436(20.4 \%)$ & $365(14.5 \%)$ & $292(14.6 \%)$ & $283(13.1 \%)$ \\
\hline House chore & $310(16.4 \%)$ & $243(9.3 \%)$ & $418(21.0 \%)$ & $286(11.1 \%)$ & $459(24.7 \%)$ & $408(19.6 \%)$ \\
\hline Lifting or carrying & $317(15.7 \%)$ & $244(8.3 \%)$ & $439(21.1 \%)$ & $363(12.8 \%)$ & $500(26.7 \%)$ & $463(21.6 \%)$ \\
\hline Standing up from armless chair & $291(15.3 \%)$ & $210(7.6 \%)$ & $439(21.3 \%)$ & $325(12.6 \%)$ & $565(29.9 \%)$ & $471(21.2 \%)$ \\
\hline Going out to movies, events & $264(13.7 \%)$ & $191(7.0 \%)$ & $331(16.2 \%)$ & $244(9.0 \%)$ & $399(20.7 \%)$ & $343(15.8 \%)$ \\
\hline Getting in and out of bed & $269(13.1 \%)$ & $210(6.6 \%)$ & $322(13.1 \%)$ & $244(8.0 \%)$ & $324(15.4 \%)$ & $264(11.6 \%)$ \\
\hline Reaching up over head & $255(12.6 \%)$ & $207(6.7 \%)$ & $337(15.9 \%)$ & $289(10.8 \%)$ & $389(20.4 \%)$ & $324(15.5 \%)$ \\
\hline Attending social event & $206(11.0 \%)$ & $150(5.8 \%)$ & $255(10.6 \%)$ & $187(7.0 \%)$ & $287(15.4 \%)$ & $257(11.2 \%)$ \\
\hline Walking for a quarter mile & $189(11.0 \%)$ & $175(7.2 \%)$ & $356(23.6 \%)$ & $264(12.2 \%)$ & $396(29.5 \%)$ & $327(21.0 \%)$ \\
\hline Grasp/holding small objects & $201(10.6 \%)$ & $170(6.5 \%)$ & $281(13.6 \%)$ & $291(12.5 \%)$ & $338(17.8 \%)$ & $329(16.4 \%)$ \\
\hline Walking up ten steps & $148(9.3 \%)$ & $131(4.8 \%)$ & $254(17.4 \%)$ & $178(8.0 \%)$ & $290(21.4 \%)$ & $220(14.1 \%)$ \\
\hline Dressing yourself & $193(9.3 \%)$ & $147(4.8 \%)$ & $241(9.8 \%)$ & $192(7.0 \%)$ & $280(14.2 \%)$ & $241(10.1 \%)$ \\
\hline Preparing meals & $154(7.6 \%)$ & $84(2.8 \%)$ & $156(7.6 \%)$ & $108(4.1 \%)$ & $185(9.3 \%)$ & $177(8.0 \%)$ \\
\hline Walking between rooms & $147(7.1 \%)$ & $88(2.7 \%)$ & $183(8.3 \%)$ & $113(3.7 \%)$ & $263(13.3 \%)$ & $213(9.5 \%)$ \\
\hline Leisure activity at home & $99(4.8 \%)$ & $79(2.4 \%)$ & $106(4.5 \%)$ & $96(3.2 \%)$ & $127(6.0 \%)$ & $103(4.4 \%)$ \\
\hline \multirow[t]{2}{*}{ Using fork, knife, drinking from cup } & $73(4.1 \%)$ & $74(2.3 \%)$ & $106(4.2 \%)$ & $75(2.8 \%)$ & $129(6.7 \%)$ & $130(5.6 \%)$ \\
\hline & \multicolumn{6}{|c|}{ Mean (SE) } \\
\hline Number of Limitations & $2.2(0.1)$ & $1.6(0.1)^{*}$ & $3.2(0.1)$ & $2.3(0.1)^{*}$ & $4.2(0.1)$ & $3.5(0.1)^{*}$ \\
\hline Combined Grip Strength (kg) & $71.8(1.1)$ & $70.5(0.7)$ & $66.7(0.8)$ & $65.8(0.6)$ & $56.6(0.6)$ & $54.8(0.6)^{*}$ \\
\hline
\end{tabular}

a. Protein intake recommendation computed as $0.8 \mathrm{~g}$ of dietary protein per kilogram of body weight; b. Mean adjusted for race/ethnicity, gender, marital status and percent of federal poverty rate; *Significantly $(\mathrm{P}<0.05)$ different between below or meeting the protein recommendation within the age category

age group, suggests that a greater effort is required to improve the diet quality of the 51-60 year old's to help reduce their risk of developing additional chronic conditions and improve their diet as they age. In light of the poor dietary habits of US adults in these data and in other analyses (40), and the rise of obesity and other chronic disease at even younger ages (41-43), lifelong dietary improvement strategies are needed to support healthful aging and disease prevention and treatment (30).

This analysis found a positive association between achieving the recommended protein intake and self-reported physical functioning. The functional limitations associated with not meeting the protein requirement were all related to activities of daily living such as stooping, crouching or kneeling, standing or sitting for long periods, walking up 10 steps, preparing meals, and walking for a quarter mile. This agrees with findings from the Framingham Offspring Study where those with a protein intake less than the recommended level $(0.8 \mathrm{~g} / \mathrm{kg} / \mathrm{d})$ were associated with a higher risk of becoming dependent in one or more of the functional tasks assessed at follow up (heavy house work, walking half a mile, going up and down stairs, stooping/kneeling/crouching, and lifting heavy items)
(44). Mishra et al., found no relationship between consuming $>25 \mathrm{~g}$ protein at two or more meals and grip strength when protein intake was expressed in terms of ideal body weight and in an unadjusted model (45); the adjusted model only found a positive association for women. This suggests gender differences but women also had lower total daily intakes of protein although may be higher if adjusted for weight (not reported by the authors).

Higher protein diets have been shown to increase physical functioning, particularly with activities such as walking half a mile, going up and down stairs, stooping, kneeling, crouching and lifting heavy items (46). All which were more commonly experienced limitations for those not consuming adequate protein in this analysis. In addition, provision of protein beyond its recommendations is associated with fewer impairments in upper and lower extremity function than in those not meeting protein recommendations (47). Future research could explore the relationship between protein intakes and physical functioning longitudinally. However, habitual activity levels (exercise) will always be a confounder in these studies, as the combination of activity and higher protein is associated with a 


\section{THE JOURNAL OF NUTRITION, HEALTH \& AGINGC}

greater reduction in risk of functional loss (44).

There is a general consensus recommending dietary protein intakes of $1-1.2 \mathrm{~g} / \mathrm{kg} / \mathrm{d}$ for the healthy population and higher for older adults and individuals with acute or chronic disease (up to $2 \mathrm{~g} / \mathrm{kg} / \mathrm{d}$ ) depending on the clinical condition, to maintain physical function $(3,8,48-51)$. Others suggest that older people should consume $0.4 \mathrm{~g} / \mathrm{kg} / \mathrm{meal}$ to limit muscle mass loss [4]. This is in line with other investigators who recommend more protein at each meal, and not focus on the total daily intake, as a means to maximize muscle protein synthesis throughout the day (52), with Mamerow et al. proposing that $30 \mathrm{~g}$ of high quality protein at breakfast, lunch and dinner will better stimulate muscle protein synthesis (53). However, if the protein recommendations are increased, the proportion of older adults below the recommendation will also increase. Therefore, strategies to help increase dietary protein could also be considered along with the recommendations. Given the heterogeneity of the older population in relation to activity level, body composition and chronic conditions, clinicians and dietitians' may help promote higher protein intakes through personalized dietary recommendations accounting for individual needs, medical comorbidities, current medications, and current food intake $(54,55)$.

Another issue with increasing protein requirements is how to obtain it, especially at each meal. Active adults seem to use supplements with protein more often (56), indicating there may be a perception that more protein is only needed if one is engaged in regular activities. There are gaps in the literature regarding methods to increase dietary protein above $0.8 \mathrm{~g} / \mathrm{kg} / \mathrm{d}$ using food only; oral nutritional supplements (ONS), protein only or mixed, are the standard way to increase protein intakes in human studies. Therefore, when food alone is insufficient to meet a patient's needs, ONS may provide a means to meet protein intake recommendations. ONS have already been shown to be beneficial for older adults by improving muscle mass and lower extremity functioning (57), and reestablish energy balance among older men and women $(58,59)$, as well as combatting weight loss (27) in nutritionally compromised individuals. To some extent, sarcopenia can be managed with protein supplementation (60), considering all the factors that are working to reduce food intake in aging. Overall, ONS may provide a plethora of benefits to the aging population and should be considered as a nutritional strategy for improving protein, and other nutrient, intakes.

While the results presented here suggest not meeting the recommended protein intake may be an issue for older adults there are limitations that must be considered. National surveillance data are useful to assess patterns related to health, however, the assessment of dietary intakes and quality is limited by the use of a singular 24-hour recall that may not reflect usual intakes. Also, the single day of recall for dietary intake may be subjective to recall bias and social desirability bias, with the potential for under- and over-reporting of food intakes. In addition, physical functioning limitations are self-reported. Furthermore, these analyses do not represent nutritional adequacy, but meeting recommended intake levels and cannot be interpreted as causal for functional outcomes. However, patterns of nutrient intakes for those meeting or not meeting protein recommendations utilizing a nationally representative sample illuminate broader nutritional and dietary pattern concerns in the aging population.

\section{Conclusion}

Overall diet quality among adults aged 51 years and older needs improvement and dietary protein intakes are falling below the current recommendation level. Individuals not meeting the protein recommendation also have lower diet quality, and are more likely to not meet recommended intakes for micronutrients which have antioxidant or immune modulating activity including zinc, selenium, vitamin E, vitamin $\mathrm{C}$, and vitamin D. Furthermore, not consuming enough protein limits functionality and may result in lower muscle mass. Future research is needed to assess the association between protein intakes, diet quality, and physical functioning longitudinally among the growing aging population.

The associations between reduced protein intakes, poorer diet quality, aging, and physical functioning reported here could help guide dietary counseling for those 51 years or older. Nutrition screening procedures should not be limited to the oldest adults and could begin with those over 50 years of age.

Sources of funding: The study was supported by a grant from Abbott Nutrition.

Sponsor's role: Collaboration on research question development and manuscript preparation

Conflicts of Interest: (OK, ML) report employment by Abbott Nutrition. CT reports travel expenses and Honoria for scientific presentations.

Ethics declaration: The National Center for Health Statistics' Research Ethics Review Board reviewed and approved all data collection protocols.

Sources of Support: R01AG037547, P30AG031679, 1UL1TR001430, UL1TR001102, P30DK046200 Abbott Laboratories, Bariatrix Nutrition Corp., and the National Dairy Council.

ClinicalTrials.gov Identifier: NCT01275365 Financial Disclosures: Authors (CMA, MRS, SB, ACM, MS, SB, LLM) report grants from National Institutes of Health, nonfinancial support from Abbott Laboratories, nonfinancial support from Bariatrix Nutrition Corporation, and non-financial support from National Dairy Countil, to their institutions during the conduct of the study. Dr. Apovian reports personal fees from Nutrisystem, personal fees from Zafgen, personal fees from Sanofi-Aventis, grants and personal fees from Orexigen, personal fees from NovoNordisk, grants from Aspire Bariatrics, grants and personal fees from GI Dynamics, grants from Myos, grants and personal fees from Takeda, personal fees from Scientific Intake, grants and personal fees from Gelesis, other from Science-Smart LLC, personal fees from Merck, personal fees from Johnson and Johnson, grants from Vela Foundation, grants from Dr. Robert C. and Veronica Atkins Foundation, grants from Coherence Lab, grants from Energesis, grants from PCORI, outside the submitted work. Dr. Bhasin reports grants from MIB, grants from AbbVie, grants from Transition Therapeutics, during the conduct of the study; personal fees from Novartis, personal fees from AbbVie, other from FPT, outside the submitted work. In addition, Dr. Bhasin has a patent on method of determining free testosterone pending. Dr. Campbell reports grants and personal fees from National Dairy Council, grants and non-financial support from National Cattlemen's Beef Association, grants from American Egg Board, grants from National Pork Board, and personal fees from Coca-Cola Foundation, outside the submitted work

Conflict of Interest: Drs. Apovian, Bhasin, and Moore report grants from the National Institutes of Health, non-financial support from Abbott Laboratories, non-financial support 


\section{LOW DIETARY PROTEIN INTAKES AND ASSOCIATED DIETARY PATTERNS AND FUNCTIONAL LIMITATIONS}

from Bariatrix Nutrition Corporation, and non-financial support from National Dairy Countil, to their institutions during the conduct of the study. There are no other conflicts of interest. Ethical standard: The study protocol was approved by the Institutional Review Boards

Open Access: This article is distributed under the terms of the Creative Commons Attribution 4.0 International License (http://creativecommons.org/licenses/by/4.0/), which permits use, duplication, adaptation, distribution and reproduction in any medium or format, as long as you give appropriate credit to the original author(s) and the source, provide a link to the Creative Commons license and indicate if changes were made.

\section{References}

1. Arthur ST, Cooley ID. The effect of physiological stimuli on sarcopenia; impact of Notch and Wnt signaling on impaired aged skeletal muscle repair. Int J Biol Sc 2012;8 (5):731-760. doi:10.7150/ijbs.4262

2. Trombetti A, Reid KF, Hars M, Herrmann FR, Pasha E, Phillips EM, Fielding RA. Age-associated declines in muscle mass, strength, power, and physical performance: impact on fear of falling and quality of life. Osteoporos Int 2016;27 (2):463-471. doi:10.1007/s00198-015-3236-5

3. Nowson C, O'Connell S. Protein Requirements and Recommendations for Older People: A Review. Nutrients 2015;7 (8):6874-6899. doi:10.3390/nu7085311

4. Lancha AH, Jr., Zanella R, Jr., Tanabe SG, Andriamihaja M, Blachier F. Dietary protein supplementation in the elderly for limiting muscle mass loss. Amino Acids 2017;49 (1):33-47. doi:10.1007/s00726-016-2355-4

5. Fulgoni VL, 3rd. Current protein intake in America: analysis of the National Health and Nutrition Examination Survey, 2003-2004. Am J Clin Nutr 2008;87 (5):1554S-1557S. doi:10.1093/ajcn/87.5.1554S

6. Volpi E, Campbell WW, Dwyer JT, Johnson MA, Jensen GL, Morley JE, Wolfe RR. Is the optimal level of protein intake for older adults greater than the recommended dietary allowance? J Gerontol A Biol Sci Med Sci 2013;68 (6):677-681. doi:10.1093/ gerona/gls229

7. Drewnowski A, Shultz JM. Impact of aging on eating behaviors, food choices, nutrition, and health status. J Nutr Health Aging 2001;5 (2):75-79

8. Deutz NE, Bauer JM, Barazzoni R, Biolo G, Boirie Y, Bosy-Westphal A, Cederholm T, Cruz-Jentoft A, Krznaric Z, Nair KS, Singer P, Teta D, Tipton K, Calder PC Protein intake and exercise for optimal muscle function with aging: recommendations from the ESPEN Expert Group. Clin Nutr 2014;33 (6):929-936. doi:10.1016/j. clnu.2014.04.007

9. Campbell WW, Crim MC, Dallal GE, Young VR, Evans WJ. Increased protein requirements in elderly people: new data and retrospective reassessments. Am J Clin Nutr 1994;60 (4):501-509. doi:10.1093/ajen/60.4.501

10. Campbell WW, Johnson CA, McCabe GP, Carnell NS. Dietary protein requirements of younger and older adults. Am J Clin Nutr 2008;88 (5):1322-1329. doi:10.3945/ ajen.2008.26072

11. Campbell WW, Trappe TA, Wolfe RR, Evans WJ. The recommended dietary allowance for protein may not be adequate for older people to maintain skeletal muscle. J Gerontol A Biol Sci Med Sci 2001;56 (6):M373-380

12. Millward DJ, Fereday A, Gibson N, Pacy PJ. Aging, protein requirements, and protein turnover. Am J Clin Nutr 1997;66 (4):774-786. doi:10.1093/ajen/66.4.774

13. Courtney-Martin G, Ball RO, Pencharz PB, Elango R. Protein Requirements during Aging. Nutrients 2016;8(8): E492. doi:10.3390/nu8080492

14. Burd NA, Gorissen SH, van Loon LJ. Anabolic resistance of muscle protein synthesis with aging. Exerc Sport Sci Rev 2013;41 (3):169-173. doi:10.1097/ JES.0b013e318292f3d5

15. Ilich JZ, Kelly OJ, Inglis JE. Osteosarcopenic Obesity Syndrome: What Is It and How Can It Be Identified and Diagnosed? Curr Gerontol Geriatr Res 2016;7325973. doi: $10.1155 / 2016 / 7325973$

16. USDA Food and Nutrient Database for Dietary Studies 2011-2012. https://www.ars. usda.gov/northeast-area/beltsville-md-bhnrc/beltsville-human-nutrition-researchcenter/food-surveys-research-group/docs/fndds-versions-and-citations/ba/bhnrc/fsrg 2014.

17. Bowman SA CJ, Friday JE, Lynch KL, and Moshfegh AJ. Food Patterns Equivalents Database 2013-14: Methodology and User Guide [Online]. Beltsville, Maryland, 2017

18. Institute of Medicine (U.S.). Subcommittee on Interpretation and Uses of Dietary Reference Intakes., Institute of Medicine (U.S.). Subcommittee on Upper Reference Levels of Nutrients., Institute of Medicine (U.S.). Standing Committee on the Scientific Evaluation of Dietary Reference Intakes. Dietary reference intakes. Applications in dietary assessment : a report of the Subcommittees on Interpretation and Uses of Dietary Reference Intakes and the Standing Committee on the Scientific Evaluation of Dietary Reference Intakes, Food and Nutrition Board, Institute of Medicine. National Academy Press, Washington, D.C. 2000

19. Krebs-Smith SM, Pannucci TE, Subar AF, Kirkpatrick SI, Lerman JL, Tooze JA, Wilson MM, Reedy J. Update of the Healthy Eating Index: HEI-2015. J Acad Nutr Diet 2018;118 (9):1591-1602. doi:10.1016/j.jand.2018.05.021

20. United States. Department of Health and Human Services., United States. Department of Agriculture., United States. Dietary Guidelines Advisory Committee. Dietary guidelines for Americans, 2015-2020. Eighth edition. edn. U.S. Department of Health and Human Services and U.S. Department of Agriculture, Washington, D.C 2015.

21. Wischmeyer PE. Tailoring nutrition therapy to illness and recovery. Crit Care 2017;21
(Suppl 3):316. doi:10.1186/s13054-017-1906-8

22. Berryman CE, Lieberman HR, Fulgoni VL, 3rd, Pasiakos SM. Protein intake trends and conformity with the Dietary Reference Intakes in the United States: analysis of the National Health and Nutrition Examination Survey, 2001-2014. Am J Clin Nutr 2018;108 (2):405-413. doi:10.1093/ajen/nqy088

23. Cruz-Jentoft AJ, Landi F, Schneider SM, Zuniga C, Arai H, Boirie Y, Chen LK, Fielding RA, Martin FC, Michel JP, Sieber C, Stout JR, Studenski SA, Vellas B, Woo J, Zamboni M, Cederholm T. Prevalence of and interventions for sarcopenia in ageing adults: a systematic review. Report of the International Sarcopenia Initiative (EWGSOP and IWGS). Age Ageing 2014;43 (6):748-759. doi:10.1093/ageing/afu115

24. Hiza HA, Casavale KO, Guenther PM, Davis CA. Diet quality of Americans differs by age, sex, race/ethnicity, income, and education level. J Acad Nutr Diet 2013;113 (2):297-306. doi:10.1016/j.jand.2012.08.011

25. Engel JH, Siewerdt F, Jackson R, Akobundu U, Wait C, Sahyoun N. Hardiness, Depression, and Emotional Well-Being and Their Association with Appetite in Older Adults. Journal of the American Geriatrics Society 2011;59 (3):482-487. doi:10.1111/ j.1532-5415.2010.03274.x

26. Lee JS, Kritchevsky SB, Tylavsky F, Harris TB, Ayonayon HN, Newman AB. Factors associated with impaired appetite in well-functioning community-dwelling older adults. J Nutr Elder 2006;26 (1-2):27-43. doi:10.1300/J052v26n01_02

27. Nieuwenhuizen WF, Weenen H, Rigby P, Hetherington MM. Older adults and patients in need of nutritional support: review of current treatment options and factors influencing nutritional intake. Clin Nutr 2010;29 (2):160-169. doi:10.1016/j. clnu.2009.09.003

28. Schiffman SS. Taste and smell losses in normal aging and disease. JAMA 1997;278 (16): $1357-1362$

29. Solemdal K, Sandvik L, Willumsen T, Mowe M, Hummel T. The impact of oral health on taste ability in acutely hospitalized elderly. PLoS One 2012;7 (5):e36557. doi:10.1371/journal.pone.0036557

30. Morley JE. Aging successfully needs lifelong prevention strategies. European Geriatric Medicine 2016;7 (4):285-288. doi:10.1016/j.eurger.2016.04.006

31. Pilgrim AL, Robinson SM, Sayer AA, Roberts HC. An overview of appetite decline in older people. Nurs Older People 2015;27 (5):29-35. doi:10.7748/nop.27.5.29.e697

32. Netz Y, Wu MJ, Becker BJ, Tenenbaum G. Physical activity and psychological wellbeing in advanced age: a meta-analysis of intervention studies. Psychol Aging 2005;20 (2):272-284. doi:10.1037/0882-7974.20.2.272

33. Lattimer JM, Haub MD. Effects of dietary fiber and its components on metabolic health. Nutrients 2010;2 (12):1266-1289. doi:10.3390/nu2121266

34. Montgomery SC, Streit SM, Beebe ML, Maxwell PJt. Micronutrient Needs of the Elderly. Nutr Clin Pract 2014;29 (4):435-444. doi:10.1177/0884533614537684

35. Prasad AS (2008) Zinc in human health: effect of zinc on immune cells. Mol Med 200814 (5-6):353-357. doi:10.2119/2008-00033

36. Rehm CD, Monsivais P, Drewnowski A. Relation between diet cost and Healthy Eating Index 2010 scores among adults in the United States 2007-2010. Prev Med 2015;73:70-75. doi:10.1016/j.ypmed.2015.01.019

37. Rehm CD, Penalvo JL, Afshin A, Mozaffarian D, Dietary Intake Among US Adults, 1999-2012. JAMA 2016;315 (23):2542-2553. doi:10.1001/jama.2016.7491

38. Eicher-Miller HA, Boushey CJ, How Often and How Much? Differences in Dietary Intake by Frequency and Energy Contribution Vary among U.S. Adults in NHANES 2007-2012. Nutrients 2017:9(1):86. doi:10.3390/nu9010086

39. Ervin RB. Healthy Eating Index scores among adults, 60 years of age and over, by sociodemographic and health characteristics: United States, 1999-2002. Advance data from vital and health statistics; no 395. National Center for Health Statistics, Hyattsville, MD, 2008

40. Shlisky J, Bloom DE, Beaudreault AR, Tucker KL, Keller HH, Freund-Levi Y, Fielding RA, Cheng FW, Jensen GL, Wu D, Meydani SN. Nutritional Considerations for Healthy Aging and Reduction in Age-Related Chronic Disease. Adv Nutr 2017;8 (1):17-26. doi:10.3945/an.116.013474

41. Ogden CL, Carroll MD, Kit BK, Flegal KM. Prevalence of childhood and adult obesity in the United States, 2011-2012. JAMA 2014;311 (8):806-814. doi:10.1001/ jama.2014.732

42. Ward BW. Barriers to health care for adults with multiple chronic conditions: United States, 2012-2015. NCHS data brief, no 275. Hyattsville, MD, 2017

43. Ward BW, Schiller JS, Goodman RA. Multiple chronic conditions among US adults: a 2012 update. Prev Chronic Dis 2014;11:E62. doi:10.5888/pcd11.130389

44. Mustafa J, Ellison RC, Singer MR, Bradlee ML, Kalesan B, Holick MF, Moore LL. Dietary Protein and Preservation of Physical Functioning Among Middle-Aged and Older Adults in the Framingham Offspring Study. Am J Epidemiol 2018;187 (7):14111419. doi:10.1093/aje/kwy014

45. Mishra S, Goldman JD, Sahyoun NR, Moshfegh AJ. Association between dietary protein intake and grip strength among adults aged 51 years and over: What We Eat in America, National Health and Nutrition Examination Survey 2011-2014. Plos One 2018;13 (1):e0191368. doi:ARTN e019136810.1371/journal.pone.0191368

46. Kranz S, Brauchla M, Campbell WW, Mattes RD, Schwichtenberg AJ. High-Protein and High-Dietary Fiber Breakfasts Result in Equal Feelings of Fullness and Better Diet Quality in Low-Income Preschoolers Compared with Their Usual Breakfast. The Journal of Nutrition 2017;147 (3):445-452

47. Gregorio L, Brindisi J, Kleppinger A, Sullivan R, Mangano KM, Bihuniak JD, Kenny AM, Kerstetter JE, Insogna KL. Adequate Dietary Protein Is Associated with Better Physical Performance among Post-Menopausal Women 60-90 Years. Journal of Nutrition Health \& Aging 2014;18 (2):155-160. doi:DOI 10.1007/s12603-013-0391-2 


\section{THE JOURNAL OF NUTRITION, HEALTH \& AGINGC}

48. Bauer J, Biolo G, Cederholm T, Cesari M, Cruz-Jentoft AJ, Morley JE, Phillips S, Sieber C, Stehle P, Teta D, Visvanathan R, Volpi E, Boirie Y. Evidence-based recommendations for optimal dietary protein intake in older people: a position pape from the PROT-AGE Study Group. J Am Med Dir Assoc 2013;14 (8):542-559. doi:10.1016/j.jamda.2013.05.021

49. Baum JI, Kim IY, Wolfe RR. Protein Consumption and the Elderly: What Is the Optimal Level of Intake? Nutrients 2016;8(6): E359. doi:10.3390/nu8060359

50. Wolfe RR, Miller SL, Miller KB. Optimal protein intake in the elderly. Clin Nutr 2008;27 (5):675-684. doi:10.1016/j.clnu.2008.06.008

51. Kelly OJ, Gilman JC, Kim Y, Ilich JZ. Macronutrient Intake and Distribution in the Etiology, Prevention and Treatment of Osteosarcopenic Obesity. Curr Aging Sci 2017:10 (2):83-105. doi:10.2174/1874609809666160509122558

52. Murphy CH, Oikawa SY, Phillips SM. Dietary Protein to Maintain Muscle Mass in Aging: A Case for Per-meal Protein Recommendations. J Frailty Aging 2016;5 (1):49 58. doi:10.14283/jfa.2016.80

53. Mamerow MM, Mettler JA, English KL, Casperson SL, Arentson-Lantz E, SheffieldMoore M, Layman DK, Paddon-Jones D. Dietary protein distribution positively influences 24-h muscle protein synthesis in healthy adults. J Nutr 2014;144 (6):876880. doi:10.3945/jn.113.185280

54. Marzetti E, Calvani R, Landi F, Hoogendijk EO, Fougere B, Vellas B, Pahor M Bernabei R, Cesari M, Consortium S. Innovative Medicines Initiative: The SPRINTT Project. J Frailty Aging 2015;4 (4):207-208

55. Schlenker ED. Healthy Aging: Nutrition Concepts for Older Adults. In: Temple N., Wilson T., G B (eds) Nutrition Guide for Physicians and Related Healthcare
Professionals. Springer International Publishing, Cham, Switzerland, 2017;pp 51-60

56. Pasiakos SM, McLellan TM, Lieberman HR. The effects of protein supplements on muscle mass, strength, and aerobic and anaerobic power in healthy adults: a systematic review. Sports Med 2015;45 (1):111-131. doi:10.1007/s40279-014-0242-2

57. Bauer JM, Verlaan S, Bautmans I, Brandt K, Donini LM, Maggio M, McMurdo ME, Mets T, Seal C, Wijers SL, Ceda GP, De Vito G, Donders G, Drey M, Greig C, Holmback U, Narici M, McPhee J, Poggiogalle E, Power D, Scafoglieri A, Schultz R, Sieber CC, Cederholm T. Effects of a vitamin D and leucine-enriched whey protein nutritional supplement on measures of sarcopenia in older adults, the PROVIDE study: a randomized, double-blind, placebo-controlled trial. J Am Med Dir Assoc 2015;16 (9):740-747. doi:10.1016/j.jamda.2015.05.021

58. Leidy HJ. Consumption of protein beverages as a strategy to promote increased energy intake in older adults. Am J Clin Nutr 2017;106 (3):715-716. doi:10.3945/ ajen.117.164160

59. Giezenaar C, Trahair LG, Luscombe-Marsh ND, Hausken T, Standfield S, Jones KL, Lange K, Horowitz M, Chapman I, Soenen S. Effects of randomized wheyprotein loads on energy intake, appetite, gastric emptying, and plasma gut-hormone concentrations in older men and women. Am J Clin Nutr 2017;106 (3):865-877. doi:10.3945/ajen.117.154377

60. Kurpad AV, Vaz M. Protein and amino acid requirements in the elderly. European Journal of Clinical Nutrition 2000:54:S131-S142 